\title{
Identifikasi Kemampuan Pengarahan Diri (Self Direction) Siswa Kelas X
}

\author{
Trya Meryanti ${ }^{1)}$, Iip Istirahayu ${ }^{2)}$ \\ ${ }^{1)}$ Prodi Bimbingan dan Konseling STKIP Singkawang \\ e-mail:Trya_Meryanti@yahoo.com \\ ${ }^{2)}$ Prodi Bimbingan dan Konseling STKIP Singkawang \\ e-mail:iip_istirahayu@yahoo.com
}

\begin{abstract}
Abstrak. Penelitian ini bertujuan untuk mengetahui mengetahui profil pengarahan diri (self direction) siswa. Metode penelitian kuantitatif. Populasi penelitian adalah siswa kelas X di salah satu SMA Negeri kota Singkawang. Pengambilan sampel dalam penelitian ini adalah sampling purposive.Instrumen pengumpulan data menggunakan angket. Analisis data menggunakan teknik analisis data statistik inferensial dengan menggunakan kurva $Z$ skor. Hasil penelitian menunjukkan bahwa Profil pengarahan diri (self direction) siswa kelas X di salah satu SMA berada pada kategori rendah dengan persentase $33,3 \%$. Sebesar $52,4 \%$ berada pada kategori sedang. Selanjutnya, sebesar $14,3 \%$ siswa berada pada kategori tinggi.
\end{abstract}

Kata kunci: Identifikasi, Pengarahandiri (self direction).

\section{Pendahuluan}

Dalam UU No 20 Tahun 2003 pasal 1 ayat 1, menyatakan bahwa Pendidikan adalah usaha sadar dan terencana untuk mewujudkan suasana belajar dan proses pembelajaran agar peserta didik secara aktif mengembangkan potensi dirinya untuk memiliki kekuatan spiritual keagamaan, pengendalian diri, kepribadian, kecerdasan, akhlak mulia, serta keterampilan yang diperlukan dirinya, masyarakat, bangsa dan negara.

Pentingnya pengarahan diri (self direction) bagi siswa seyogyanya agar siswa mempunyai kepribadian yang baik meliputi rasa percaya diri yang baik, mempunyai rasa tanggung jawab dalam tugas belajar, dan siswa mempunyai pengendalian dalam dirinya. Hasil wawancara yang dilakukan terhadap Guru BK di salah satu SMA mengenai pengarahan diri (self direction), dikatakan bahwa di sekolah tersebut juga terdapat siswa yang kurang dalam pengarahan diri (self direction).

Rendahnya pengarahan diri (self direction) pada diri siswa ditunjukan dengan kurangnya percaya diri, mencontek pada saat ujian, tidak mengerjakan tugas yang diberikan oleh guru, dan kurangnya pengendalian diri siswa. Siswa yang self direction kurang baik mengakibatkan prestasi belajar menurun, dan hubungan sosial menjadi kurang baik.

\section{Metode Penelitian}

Jenis penelitian yang digunakan adalah penelitian kuantitatif. Populasi dalam penelitian ini adalah siswa kelas XC di salah satu SMA Negeri kota Singkawang. Teknik pengambilan sampel dalam penelitian ini adalah sampling purposive. Teknik pengumpulan data yang akan digunakan dalam penelitian ini adalah teknik non tes yaitu dengan kuisioner (angket) skala pengarahan diri (self direction). Untuk mengetahui profil pengarahan diri (self direction) siswa kelas $\mathrm{X}$, peneliti menggunakan analisis statistik inferensial. Statistik inferensial mampu untuk membuat gambaran atau kesimpulan tentang parameter suatu populasi berdasarkan statistik atau ukuran-ukuran yang diperoleh dari sampel [1]

\section{Hasil Dan Pembahasan}

Profil pengarahan diri (self direction) siswa dianalisis menggunakan analisis skor. Data profil pengarahan diri (self direction) siswa pada tabel di bawah ini.

Tabel I

Kategori pengarahan diri (self direction) siswa kelas XC

\begin{tabular}{|l|l|l|c|}
\hline Kategori & $Z$ score & Frekuensi & Persentase \\
\hline Tinggi & $Z>1$ & 3 & $14,3 \%$ \\
\hline Sedang & $-1 \leq Z \leq 1$ & 11 & $52,4 \%$ \\
\hline Rendah & $Z<-1$ & 7 & $33,3 \%$ \\
\hline \multicolumn{2}{|c|}{ Jumlah } & 21 & $100 \%$ \\
\hline \multicolumn{4}{|c|}{ (Furqon, 2011:140) }
\end{tabular}

Tabel 3 menjelaskan bahwa, 7 orang siswa kelas XC berada pada persentase 33,3\% dengan kategori rendah. Artinya siswa kurang memiliki kepercayaan diri yang baik meliputi kurang yakin dengan diri sendiri, kurang mampu menilai diri secara positif, kurang berani mengemukakan pendapat, kurang berani mengajukan pertanyaan kurang memahami dalam memenuhi pemenuhan kebutuhan, serta 
kurang mampu untuk mengendalikan diri yang di tunjukan dengan kurang mampunya siswa untuk mengekspresikan emosi, kurang mampu dalam mengatasi reaksi yang menyertai kemunculan emosi, dan melakukan sesuatu diluar rencana.

Siswa kelas XC yang berada pada kategori sedang pada persentase lebih dari 50\%(11 siswa dari 21 siswa). Artinya siswa masih merasa ragu dalam hal percaya diri yang ditunjukan dengan sikap ragu dalam keyakinan diri, ragu menilai diri secara positif, masih malu dalam mengajukan pertanyaan dan mengemukakan pendapat, dan ragu dalam memahami pemenuhan kebutuhan yang di tunjukan dengan sikap ragu dalam memenuhi dan memahami kebutuhan hidup, serta masih ragu dalam pengendalian diri yang ditunjukan dari perilaku terkadang bisa menahan emosi namun terkadang tidak bisa, sedikit mampu dalam mengatasi reaksi yang menyertai kemunculan emosi, dan ragu dalam mencapai pencapaian tujuan kegiatan.

Sebanyak 14,3\%(3 orang) siswa kelas XC berada presentase kategori tinggi. Artinya siswa mempunyai rasa percaya diri yang baik, ditunjukan dengan mempunyai keyakinan diri yang baik, menilai diri secara positif, berani mengemukakan pendapat, berani mengajukan pertanyaan dan mampu memahami dalam memenuhi pemenuhan kebutuhan hidup, dan mampu mengendalikan diri dengan ditunjukan sikap dan perilaku tenang dalam mengekspresikan emosi dan merencanakan pencapaian kegiatan dengan baik.

\section{Simpulan dan Saran}

Profil pengarahan diri (self direction) siswa kelas $\mathrm{X}$ di salah satu SMA berada pada kategori rendah dengan persentase $33,3 \%$. Sebesar $52,4 \%$ berada pada kategori sedang. Selanjutnya, sebesar $14,3 \%$ siswa berada pada kategori tinggi.

Saran yang dapat diberikan kepada guru BK adalah dapat menggunakan profil yang ada dalam menentukan materi atau memberikan bimbingan dan layanan yang sesuai dengan kebutuhan siswa, sedangkan untuk peneliti selanjutnya dapat menggunakan hasil penelitian sebagai studi pendahuluan atau referensi dalam penelitiannya.

\section{Referensi}

[1] Furqon. (2011). Statistika Penerapan Untuk Penelitian. Bandung: Alfabeta.

[2] Istirahayu, I. dan Yusuf, S. (2015). Identification the quantity of student' the effectiveness of theistic spiritual counseling in improving student' intrapersonal competency, Global illuminators Vol 2. (2015). (336-42).

[3] UU Nomor 20 Tahun (2003). Sistem Pendidikan Nasional. Jakarta: Tamita Jaya Utama Alfabeta. 